\title{
Appendix 2: Corporate history of LUKOIL
}

1960 The Shaimskoye oilfield was discovered in 1960. The nearby settlement of Urai became a hub for oil workers and was declared a town in 1965 (LUKOIL 2018a).

1962 The history of Langepas oil company started when the Lokosovskoye oilfield was discovered in 1959 (LUKOIL 2018a).

1972 The town of Kogalym was founded in 1975 after the discovery of oilfields in the vicinity.

1991 On 25 November 1991, the government created LangepasUraiKogalym (LUKOIL), consolidating the oil-producing enterprises of Langepas, Urai and Kogalym as well as several refineries, including those in Perm and Volgograd (LUKOIL 2018b).

1993 The Council of Ministers incorporated the public joint stock company (JSC) LUKOIL. Vagit Alekperov was appointed the company's President, CEO and chairman of the board of directors. A privatization programme was approved, and the first issue of LUKOIL shares was registered (LUKOIL 2018b).

1993 On the initiative of the company's management, the LUKOIL Charity Fund was established, one of the first corporate charity funds in post-Soviet Russia (LUKOIL 2018b).

1994 LUKOIL acquired a 10\% stake in the project for the development of Azeri-Chirag-Gyuneshli, the largest oilfield in the Azerbaijani sector of the Caspian Sea (LUKOIL 2018b).

1994 The trade unions of the major oil production, refining and petroleum product distributors of LUKOIL were merged into one trade union, the 'Inter-Regional Trade Union Organization', with a total of about 90000 members (LUKOIL 2018b).

1995 A 5\% state stake in LUKOIL was sold at a loans-for-shares auction, and $16.07 \%$ was offered in an investment tender. Shares were bought by LUKOIL itself at the loans-for-shares auction and by NIKoil in the tender (Salomon Brothers 1996).

1995 Stakes in nine oil-producing, marketing and service enterprises in Western Siberia, and the Volga-Urals regions were added to the company's authorized capital (LUKOIL 2018b).

1995 ARCO acquired a 6.3\% stake in LUKOIL and became a strategic partner (LUKOIL 2018b).

1995 LUKOIL joined the Kumkol project in Kazakhstan and the Meleya project in Egypt (LUKOIL 2018b).

1995 LUKOIL issued first-level American depository receipts (ADRs) (NGFR 2010).

1996 LUKOIL acquired a 5\% stake in the Shakh-Deniz international gas project in the Azerbaijani sector of the Caspian Sea. In 2004, the company increased its stake in the project to $10 \%$ (LUKOIL 2018b).

1996 LUKOIL and ENI established the LukAgip joint venture (NGFR 2010).

1996 LUKOIL and ARCO established LukArco joint venture (New York Times 1996). 
1996 LUKOIL began to establish its own tanker fleet (NGFR 2010).

1997 LUKOIL acquired a 15\% stake in the project for the development of Karachaganak gas field and a 5\% stake in Tengiz project, both in Kazakhstan (LUKOIL 2018b).

1997 LUKOIL Racing Team had become one of the leaders in Russian motor racing (LUKOIL 2018b).

1997 LUKOIL bought a controlling interest in Arkhangelskgeoldobycha and, in 2003, increased its stake to $99.7 \%$ (NGFR 2010).

1998 LUKOIL acquired a controlling stake in Petrotel refinery located in Ploieşti, Romania (LUKOIL 2018b).

1999 LUKOIL acquired KomiTEK, becoming a dominant player in Timan-Pechora (NGFR 2010).

1999 LUKOIL acquired controlling stakes in Odessa refinery (Ukraine), Stavropolpolymer (later renamed Stavrolen), Saratovorgsintez petrochemical plant and became the key shareholder of the Bulgarian Neftokhim petrochemical enterprise in Burgas (LUKOIL 2018b).

2000 LUKOIL started developing the Kravtsovskoye field in the Baltic Sea (NGFR 2010).

2000 Following the acquisition of ARCO, BP gained a 7\% stake in LUKOIL. In early 2001, BP announced its intention to sell the stake. In January 2003, BP started converting the bonds into the company's shares, thus withdrawing from the authorized capital of LUKOIL (LUKOIL 2018b).

2000 LUKOIL entered the US petroleum products retail market through the acquisition of Getty Petroleum Marketing, which operated 1260 service stations in 13 north-eastern states.

2001 LUKOIL acquired Yamalgazneftedobycha, a holder of subsoil use licences in the Bolshekhetskaya Depression in Yamal-Nenets Autonomous District (LUKOIL 2018b).

2001 LUKOIL acquired the state's stake in NORSI-Oil, the owner of Nizhegorodnefteorgsyntez refinery (NGFR 2010).

2001 LUKOIL bought the Lokosovskiy gas-processing complex from SIBUR (NGFR 2010).

2002 LUKOIL settled a conflict with tax authorities and voluntarily gave up the use of the so-called Baikonur scheme and paid taxes (Vedomosti 2005).

2002 LUKOIL began to divest itself of non-core assets (Forbes 2007).

2002 Sergey Kukura, Chief Financial Officer of LUKOIL, was kidnapped by five masked men (Telegraph 2002).

2002 LUKOIL signed a contract with Colombia's NOC Ecopetrol for the joint oil exploration and production at Condor block (LUKOIL 2018b).

2003 LUKOIL purchased a controlling stake in Serbia's Beopetrol, which controls about $20 \%$ of the Serbian retail fuel market (LUKOIL 2018b).

2003 President Vladimir Putin participated in the official opening ceremony of LUKOIL's service station in New York (LUKOIL 2018b).

2003 LUKOIL Overseas Egypt signed a concessionary agreement with Egypt to develop the North-East Geisum and West Geisum blocks (NGFR 2010).

2003 LUKOIL sold its stake in Azeri-Chirag-Guneshli to Inpex (Neft i kapital 2003).

2004 LUKOIL-Western Siberia began the development of the Nakhodkinskoye gas field (NGFR 2010). 
2004 ConocoPhillips submitted a winning bid to purchase a 7.59\% stake in LUKOIL previously owned by the state. In 2007, ConocoPhillips increased its stake in LUKOIL to $20 \%$ (LUKOIL 2018b).

2004 LUKOIL purchased a 50\% stake in the production-sharing agreement (PSA) for Tyub-Karagan offshore block in the Kazakh sector of the Caspian Sea (LUKOIL 2018b).

2004 LUKOIL and Saudi Aramco signed a 40-year contract for the exploration and development of gas and gas-condensate fields at Block A in Saudi Arabia (LUKOIL 2018b).

2004 LUKOIL and the Uzbekneftegaz signed a PSA for Kandym-Khauzak-Shady project giving LUKOIL a 90\% stake in the project (LUKOIL 2018b).

2004 LUKOIL started publishing biannual sustainable development reports. From 2018 they were published annually (LUKOIL 2018b).

2004 A conflict arose between LUKOIL and the Azeri tax authorities. The Azeris accused LUKOIL of tax evasion, which the company denied (REGNUM 2004).

2004 LUKOIL commissioned the first stage of the oil terminal in Vysotsk (Leningrad region) (NGFR 2010).

2005 LUKOIL discovered a major multi-reservoir oil-gas-condensate field in the Severny licence area in the northern part of the Caspian Sea (LUKOIL 2018b).

2005 LUKOIL acquired the Finnish petroleum product distributors Teboil and Suomen Petrooli (LUKOIL 2018b).

2005 LUKOIL and PDVSA signed an agreement on the development of the Junin-3 block in Venezuela (RIA 2011a).

2005 LUKOIL acquired Nelson Resources Limited, which held stakes in four production projects in Western Kazakhstan and options on two exploration blocks in the Kazakh sector of the Caspian Sea (LUKOIL 2018b).

2005 LUKOIL-Western Siberia bought $66 \%$ of Geoilbent from Novatek and in 2007 bought another $34 \%$ of Geoilbent from Russneft (NGFR 2010).

2005 LUKOIL and ConocoPhillips established the Naryanmarneftegaz joint venture (Forbes 2012).

2005 LUKOIL discovered the major oilfield Filanovskogo in the Caspian Sea (NGFR 2010).

2005 LUKOIL signed a strategic partnership agreement with Gazprom (RIA 2005).

2005 LUKOIL was Russia's first oil company to commence large-scale production of Euro-4 diesel fuel (LUKOIL 2018b).

2006 LUKOIL acquired a 63\% stake in the PSA on exploration, development and production of hydrocarbons at a deep-water block in Cote d'Ivoire (LUKOIL 2018b).

2006 LUKOIL bought producing assets in Khanty-Mansi Autonomous District from Marathon Oil (NGFR 2010).

2007 LUKOIL agreed with Vanco Energy, an American oil company, to buy a 56.66\% stake in three projects for exploration of prospective offshore blocks in the Gulf of Guinea in Western Africa (LUKOIL 2018b).

2007 The small American company Green Oil accused LUKOIL of inflating the price of its oil products in the United States (Skandaly.ru 2007). 
2008 Naryanmarneftegaz began oil production from the Yuzhno-Khylchuyusk field (Kommersant 2012a; RIA 2005).

2008 LUKOIL launched the Varandei oil terminal in the Barents Sea (LUKOIL 2019b).

2008 LUKOIL (49\%) and Italy's ERG (51\%) established a joint venture to operate ISAB, a major oil-refining facility in Sicily (LUKOIL 2018b).

2008 LUKOIL acquired Akpet, a Turkish company operating 693 service stations under dealer agreements, making up about $5 \%$ of the Turkish market (LUKOIL 2018b).

2008 LUKOIL joined the National Oil Consortium in Venezuela with a 20\% stake (Kommersant 2013).

2009 LUKOIL finalized a deal to acquire a 45\% stake in TOTAL Raffinaderij Nederland from Total (LUKOIL 2018b).

2009 LUKOIL acquired a $46 \%$ stake in the LukArco joint venture from BP. As a result, the company received a $5 \%$ stake in the Tengizchevroil joint venture, which was developing the Tengiz and Korolevskoye fields in Kazakhstan (LUKOIL 2018b).

2010 LUKOIL commissioned the Korchagin field in the Caspian Sea (LUKOIL 2019c).

2010 LUKOIL won a bid for the development of the West Qurna-2 oilfield in Iraq (LUKOIL 2018b).

2010 A high-ranking LUKOIL employee was involved in a fatal car crash but was found not guilty of causing the crash (Radio Liberty 2010).

2010 A consortium consisting of LUKOIL, American Vanco and Ghana National Petroleum Corporation discovered significant hydrocarbon reserves in the Dzata structure on Ghana's continental shelf (LUKOIL 2018b).

2011 ConocoPhillips sold its stake in LUKOIL (LUKOIL 2018b).

2011 LUKOIL purchased a 50\% stake in the Vietnamese Hanoi Trough from Quad Energy (LUKOIL 2018b),

2011 LUKOIL and Italian ERG Renew signed an agreement for the establishment of the LUKERG Renew joint venture to develop renewable energy (LUKOIL 2018b).

2011 LUKOIL acquired from Oranto Petroleum a 49\% stake in the exploration and production contract for a deep-water block outside Sierra Leone (LUKOIL 2018b).

2011 Jointly with American Vanco and PETROCI, LUKOIL made a discovery on Cote d'Ivoire's continental shelf (LUKOIL 2018b).

2011 LUKOIL sold Getty Petroleum Marketing (RIA 2011b).

2011 As part of a consortium, LUKOIL received the licence for the Trident and Rapsodia blocks in Romania (RIA 2015).

2011 Production at the Yuzhno-Khylchuyusk field began to decline and its reserves were downgraded (Forbes 2012).

2011 LUKOIL joined forces with Bashneft in the Bashneft Polyus joint venture, the licence holder for the Trebs and Titov fields in Timan-Pechora (Kommersant 2012a).

2011 LUKOIL terminated its activities on the Junin-3 block in Venezuela (RIA 2011a).

2011 LUKOIL production declined for the first time (Kommersant 2012b).

2011 The Bulgarian authorities suspected LUKOIL of fraudulent exports and revoked the licence of Neftokhim Burgas (Kommersant 2011). 
2012 Agreements were signed with Verolma Group to acquire 46 petrol stations in the Netherlands, 13 petrol stations in Belgium and eight petrol stations in Belgium from NGM Group (LUKOIL 2018b).

2012 LUKOIL sold its stake in the Condor block in Colombia (Kommersant 2012c).

2012 LUKOIL and Inpex won the licence for Block 10 in Iraq (Kommersant 2012d).

2012 LUKOIL launched the production of a new generation of engine oils at the Petrotel-LUKOIL refinery in Romania (LUKOIL 2018b).

2012 LUKOIL bought $30 \%$ of Naryanmarneftegaz from ConocoPhillips, becoming its sole owner (Forbes 2012).

2012 LUKOIL won the licence for the Imilorskoye group of fields (Kommersant 2012a).

2013 LUKOIL agreed to pay USD 93 million to settle a lawsuit arising from the bankruptcy of Getty Petroleum Marketing (World Oil 2013).

2013 LUKOIL sold its Odessa refinery (Neft I kapital 2013).

2013 LUKOIL joined two projects in the Norwegian sector of the Barents Sea (LUKOIL 2018b).

2013 The joint venture of LUKOIL and Italian ERG Renew, LUKERG Renew, acquired Land Power of Romania (LUKOIL 2018b).

2013 LUKOIL acquired a 65\% stake in an offshore block in the waters of Cote d'Ivoire in the Gulf of Guinea (LUKOIL 2018b).

2013 LUKOIL and OMV Refining \& Marketing signed a contract for the acquisition of OMV's lubricants plant outside Vienna (LUKOIL 2018b).

2013 An accident at LUKOIL's refinery in Bulgaria seriously injured four people (Sofia News Agency 2013).

2013 LUKOIL acquired the remaining $20 \%$ stake in the joint venture created to operate the ISAB refinery in Sicily from Italian ERG (LUKOIL 2018b).

2013 LUKOIL sold its stake in the National Oil Consortium to Rosneft (Kommersant 2013).

2014 LUKOIL signed a deal on oil exploration and production with Mexico's NOC Pemex (The Borgen Project 2014).

2014 In cooperation with Saudi Aramco, LUKOIL drilled two evaluation wells in the Mushaib tight gas field in the Empty Quarter (Reuters 2014).

2014 The Romanian government accused LUKOIL of tax evasion and money laundering (Vkrizis.ru 2014).

2014 A new home arena of Spartak Moscow football club was opened with LUKOIL as the general sponsor (LUKOIL 2018b).

2014 Three members of staff in connection with LUKOIL's offshore operations in Ghana were killed in a helicopter crash (Offshore Energy Today 2014).

2014 LUKOIL was added to the list of companies affected by the US sanctions against Russia (Forbes 2014).

2014 LUKOIL and Gazprom extended their partnership agreement up to 2024 (LUKOIL 2018c).

2014 LUKOIL formed a joint venture with Total to work on the Bazhenov play in Western Siberia (LUKOIL 2018b). 
2015 LUKOIL and WWF signed a cooperation agreement (LUKOIL 2018b).

2015 LUKOIL, PanAtlantic and Romgaz discovered a major offshore field in the Lira marine structure on the Romanian continental shelf (LUKOIL 2018b).

2016 LUKOIL commissioned Filanovskogo field in the Caspian Sea (LUKOIL 2019d).

2016 Azat Shamsuarov, son of LUKOIL's vice president, was involved in a car chase with the police for the third time and sentenced to 15 days in prison (Vkrizis.ru 2016).

2016 Forbes wrote that Heesen Yachts, a well-known Dutch producer of superyachts, belongs to the President of LUKOIL, Vagit Alekperov (Forbes 2015).

2016 The vice president of LUKOIL notified Bashneft that LUKOIL intended to acquire $25 \%$ of Bashneft (Skandaly.ru 2016).

2016 LUKOIL withdrew from the Rapsodia project in Romania (Neft i kapital 2017).

2016 LUKOIL withdrew from Block A in Saudi Arabia (RBC 2016a).

2016 LUKOIL sold its fuel stations in Latvia, Lithuania and Poland (RBC 2016b).

2017 LUKOIL was involved in a tax evasion case in Romania (Romania Insider 2017).

2017 Four people died in a fire at the LUKOIL plant in Kstov, Nizhegorodskoy Oblast (Ruptly 2017).

2018 LUKOIL reported 20 million tonnes of oil produced from North Caspian fields (World Oil 2018).

2018 LUKOIL rebuffed the interest of Rosneft in the Trebs and Titov project (Skandaly.ru 2018).

2019 LUKOIL started drilling new production wells at the West Qurna-2 field in Iraq (LUKOIL 2019a).

\section{REFERENCES}

Forbes (2007), 'LUKOYL pro zapas', accessed 1 March 2019 at https://www.forbes.ru/ Forbes/issue/2007-06/12377-lukoil-pro-zapas.

Forbes (2012), 'LUKOYL vykupil 30\% "Naryanmarneftegaza" u ConocoPhillips', accessed 1 March 2019 at https://www.forbes.ru/news/98270-lukoil-vykupil-30 -naryanmarneftegaza-u-conocophillips.

Forbes (2014), 'LUKOIL pod sanktsiyami: Pochemu v spisok SSHA popala chastnaya kompaniya', accessed 1 March 2019 at https://www.forbes.ru/kompanii/ resursy/267605-lukoil-pod-sanktsiyami-pochemu-v-spisok-ssha-popala-chastnaya -kompaniya.

Forbes (2015), 'Verfi Alekperova: Vladelets LUKOYla vkladyvayet v stroitelstvo elitnykh yakht', accessed 8 February 2019 at http://www.forbes.ru/milliardery/288331 -verfi-alekperova-vladelets-lukoila-vkladyvaet-v-stroitelstvo-elitnykh-yakht.

Kommersant (2011), 'LUKOYL otbil litsenziyu', accessed 1 March 2019 at https:// www.kommersant.ru/doc/1689728.

Kommersant (2012a), 'LUKOYL zabral u Rossii samoye dorogoye', accessed 1 March 2019 at https://www.kommersant.ru/doc/2098523.

Kommersant (2012b), 'LUKOYL rasplatilsya za oshibki geologov', accessed 1 March 2019 at https://www.kommersant.ru/doc/1884165.

Kommersant (2012c), 'LUKOYL vypustil Kondora', accessed 1 March 2019 at https:// www.kommersant.ru/doc/2088810.

Kommersant (2012d), 'Neftyanoye peremiriye', accessed 1 March 2019 at https://www .kommersant.ru/doc/2041743. 
Kommersant (2013), 'Venesuelu ostavyat goskompaniyam', accessed 1 March 2019 at https://www.kommersant.ru/doc/2309815.

LUKOIL (2018a), 'Predpriyatiye', accessed 8 February 2019 at http://zs.lukoil.ru/ru/ About/Structure/Langepasneftegaz.

LUKOIL (2018b), 'History', accessed 8 February 2019 at http://www.lukoil.com/ Company/history/History1991.

LUKOIL (2018c), 'LUKOIL i Gazprom zaklyuchili soglasheniye o namereniyakh po realizatsii proyekta razrabotki dvukh mestorozhdeniy v nao', accessed 1 March 2019 at http://www.lukoil.ru/PressCenter/Pressreleases/Pressrelease?rid=220909.

LUKOIL (2019a), 'LUKOIL begins drilling new production wells at West Qurna-2', accessed 8 February 2019 at http://www.lukoil.com/PressCenter/Pressreleases/ Pressrelease? rid $=326315$.

LUKOIL (2019b), 'Varandeyskiy terminal', accessed 1 March 2019 at http://trans .lukoil.ru/ru/About/Structure/VarandeyTerminal.

LUKOIL (2019c), 'Mestorozhdeniye im. Yu. Korchagina', accessed 1 March 2019 at http://www.lukoil.ru/Business/Upstream/KeyProjects/KorchaginField.

LUKOIL (2019d), 'Mestorozhdeniye im. V. Filanovskogo', accessed 1 March 2019 at http://www.lukoil.ru/Business/Upstream/KeyProjects/Filanovskyfield.

Neft i kapital (2003), 'LUKOYL zavershayet prodazhu svoyey doli v proyekte Azeri-Chirag-Gyuneshli INPEKSu', accessed 1 March 2019 at https://oilcapital.ru/ news/markets/28-04-2003/lukoyl-zavershaet-prodazhu-svoey-doli-v-proekte-azeri -chirag-gyuneshli-inpeksu.

Neft i kapital (2013), 'LUKOYL prodayet Odesskiy NPZ ukrainskomu VETEKu', accessed 1 March 2019 at https://oilcapital.ru/news/companies/05-03-2013/lukoyl -prodaet-odesskiy-npz-ukrainskomu-veteku.

New York Times (1996), 'ARCO looks to Russia to fill its vast appetite for oil reserves', accessed 1 March 2019 at https:/www.nytimes.com/1996/09/24/business/ arco-looks-to-russia-to-fill-its-vast-appetite-for-oil-reserves.html.

NGFR (2010), 'LUKOIL', accessed 1 March 2019 at http://www.ngfr.ru/library.html ?lukoil.

Offshore Energy Today (2014), 'LUKOIL confirms helicopter crash offshore Ghana. Three dead', accessed 9 February 2019 at https://www.offshoreenergytoday.com/ lukoil-confirms-helicopter-crash-offshore-ghana-three-dead/.

Radio Liberty (2010), 'LUKOIL official found not guilty in deadly car crash', accessed 9 February 2019 at https://www.rferl.org/a/lukoil_Official_Found_Not_Guilty_In Deadly_Car_Crash/2151590.html.

RBC (2016a), 'LUKOYL zayavil ob ukhode iz Saudovskoy Aravii', accessed 1 March 2019 at https://www.rbc.ru/rbcfreenews/5762802a9a794724eff78999.

RBC (2016b), 'LUKOYL dogovorilsya o prodazhe zapravok v Pribaltike i Polshe', accessed 1 March 2019 at https://www.rbc.ru/business/05/02/2016/ 56b497e69a7947ab333a1b5c.

REGNUM (2004), "Konflikt mezhdu "LUKOYL" i Ministerstvom nalogov Azerbaydzhana prodolzhayetsya', accessed 8 February 2019 at https://regnum.ru/ news/220131.html.

Reuters (2014), 'Russia's LUKOIL to drill for tight gas in Saudi desert', accessed 3 October 2017 at https://www.reuters.com/article/saudi-lukoil-gas/russias-lukoil-to -drill-for-tight-gas-in-saudi-desert-idUSL6N0O034G20140515.

RIA (2005), 'Gazprom i LUKOYL zaklyuchili soglasheniye o strategicheskom partnerstve', accessed 1 March 2019 at https://ria.ru/20050329/39587682.html. 
RIA (2011a), 'LUKOYL prekratil raboty po proyektu "Khunin-3" v Venesuele', accessed 1 March 2019 at https://ria.ru/20111031/476468540.html.

RIA (2011b), “Amerikanskaya "dochka" LUKOYLa prodala podrazdeleniye Getty Petroleum', accessed 1 March 2019 at https://ria.ru/20110303/341472213.html.

RIA (2015), 'LUKOYL vlozhit do $\$ 300$ mln v 2 skvazhiny na shel'fe Rumynii', accessed 1 March 2019 at https://ria.ru/20150402/1056083185.html.

Romania Insider (2017), 'LUKOIL involved in tax evasion case in Romania', accessed 9 February 2019 at https://www.romania-insider.com/lukoil-tax-evasion-romania/.

Ruptly (2017), 'Russia: Four killed in explosion at LUKOIL plant in Nizhny Novgorod - reports', accessed 8 February 2019 at https://www.youtube.com/watch $? \mathrm{v}=\mathrm{JNYE} 2 \mathrm{kAKgP} 8$.

Salomon Brothers (1996), Russian Oil Vertically Integrated Companies, Volume 3 of Report on Russian Oil, March, London: Salomon Brothers, pp. 30-1.

Skandaly.ru (2007), 'LUKOIL sgovorilsya na \$ 25 mlrd?', accessed 8 February 2019 at https://scandaly.ru/2007/08/06/lukojl-sgovorilsya-na-25-mlrd/.

Skandaly.ru (2016), 'Kontsy v LUKOYL?', accessed 8 February 2019 at http:// scandaly.ru/2016/04/20/kontsyi-v-lukoyl/.

Skandaly.ru (2018), 'Vagit Alekperov vstupil v boy s Igorem Sechinym', accessed 8 February 2019 at https://scandaly.ru/2018/10/02/vagit-alekperov-vstupil-v-boy-s -igorem-sechinyim/.

Sofia News Agency (2013), 'Accident at Bulgaria's LUKOIL refinery leaves 4 seriously injured', accessed 9 February 2019 at https://www.novinite.com/articles/156403/ Accident+at+Bulgaria $\% 27 \mathrm{~s}+$ Lukoil + Refinery+Leaves $+4+$ Seriously+Injured.

Telegraph (2002), 'LUKOIL offers $\$ 1 \mathrm{~m}$ reward to trace kidnapped executive', accessed 14 October 2017 at http://www.telegraph.co.uk/finance/2773437/Lukoil -offers-1m-reward-to-trace-kidnapped-executive.html.

The Borgen Project (2014), 'LUKOIL and PEMEX sign petroleum agreement', accessed 3 October 2017 at https://borgenproject.org/lukoil-pemex-sign-petroleum -agreement/.

Vedomosti (2005), 'LUKOYL otlozhil na nalogi \$ $163 \mathrm{mln}$ ', accessed 1 March 2019 at https://www.vedomosti.ru/newspaper/articles/2005/09/21/lukojl-otlozhil-na-nalogi $-163-\mathrm{mln}$.

Vkrizis.ru (2014), 'Rumyniya zapodozrila "LUKOYL" v uklonenii ot uplaty nalogov i otmyvanii deneg', accessed 3 October 2017 at http://vkrizis.ru/energetika/rumyiniya -zapodozrila-lukoyl-v-uklonenii-ot-uplatyi-nalogov-i-otmyivanii-deneg/.

Vkrizis.ru (2016), 'Protiv syna vitse-prezidenta "LUKOYLa" v tretiy raz vozbudili ugolovnoye delo', accessed 3 October 2017 at http://vkrizis.ru/obschestvo/protiv -syina-vitse-prezidenta-lukoyla-v-tretiy-raz-vozbudili-ugolovnoe-delo/.

World Oil (2013), 'LUKOIL to pay $\$ 93$ million to settle Getty petroleum suit', accessed 3 October 2017 at https:/www.worldoil.com/news/2013/7/18/lukoil-to -pay-93-million-to-settle-getty-petroleum-suit.

World Oil (2018), 'LUKOIL reports 20 million tonnes of oil produced from North Caspian fields', accessed 8 February 2019 at https:/www.worldoil.com/news/2018/ 12/21/lukoil-reports-20-million-tonnes-of-oil-produced-from-north-caspian-fields. 